\title{
Governance in Family Business: A Literature Review
}

\author{
Amali Ediriweera, Anona Armstrong and Kumi Heenetigala \\ Victoria University, Australia
}

\begin{abstract}
Public and academic discussion on corporate governance and its related issues are clearly visible in any country with active capital markets. This suggests that good governance is a crucial factor for ensuring economic development. However, few studies can be found relating to non-listed or smaller firms. With the aim of contributing to this knowledge gap, this study reviewed the literature specific to corporate governance in family business in an emerging market, Sri Lanka, a small developing country with average lower middle income. The development of corporate governance best practices in Sri Lanka has been strongly affected by British models and systems, which derive from the Anglo-Saxon model of corporate governance. However, previous researchers who found that ownership of many listed companies was concentrated mainly in individual shareholders or a family concluded that family business in Sri Lanka is very critical to the economic development of the country. This study presents a review of non-listed and small to medium family business, and their two-tier mechanism of governing.
\end{abstract}

\section{Key Words}

Corporate Governance, Family Business, Family Involvement

\section{Introduction}

Good governance is a crucial factor for ensuring economic development. Historically, different corporate governance systems have developed around the world due to specific political, social, economic, cultural and religious norms (Licht, Goldschmidt, \& Schwartz, 2005). Therefore, in the new global world, a convergence in corporate governance is taking place more rapidly than before. Even though corporate governance practices and codes stepped up from developed economies and spread into all over the world, these models may not be one hundred percent suitable to emerging markets such as Sri Lanka.

Though there is a vacuum in the academic literature on corporate governance practices in emerging markets, a number of studies on corporate governance can be found not only in Sri Lanka but in every corner of the world. Most of this attention has focused on large listed corporations (Gabrielsson \& Huse, 2004; Hart, 1995) and little empirical work relates to smaller business (Wellalage \& Locke, 2011) and family business. Further knowledge of corporate governance on Sri Lankan family business suffers from a deficiency of research studies. This study helps to fill this gap by adding new insight into the existing literature on corporate governance in family business in Sri Lanka.

Copyright (C) 2015 Victoria University. This document has been published as part of the Journal of Law and Governance in both online and print formats. Educational and non-profit institutions are granted a non-exclusive licence to utilise this document in whole or in part for personal or classroom use without fee, provided that correct attribution and citation are made and this copyright statement is reproduced. Any other usage is prohibited without the express permission of the publisher.

\section{Corporate Governance}

Corporate governance is a pivotal subject in business literature (Colarossi, Giorgino, Steri, \& Viviani, 2008). It concerns the exercise of power to direct and control companies (Clarke, 2004). As explained by Manawaduge (2012), corporate governance facilitates achieving company objectives, explicates the ways and means of making business decisions, stipulates the distribution of rights and responsibilities of the management and 
other stakeholders, and aligns the company behaviour with the expectation of the society . Hence, corporate governance has significant implications for the financial stability and performance of companies and thereby the economic growth of the country (Rezaee, 2009). Even though corporate governance as a concept has been acknowledged for decades, due to the Asian financial crisis in 1997 and more recently the accounting scandals in Europe and the United States, it has earned much attention worldwide. There is no universally agreed definition for what the term corporate governance means, although numerous definitions have been discussed (Anandarajah, 2004). However, defining corporate governance is a difficult exercise because of different culture, legal systems and history (Ramon, 2001). Put simply, as in Heenetigala and Armstrong (2011) and Adams et al. (2011) corporate governance is concerned with internal structures and processes for decision making, accountability, control and behaviour at the top of organization (Clarke, 2004), and mechanisms for accountability (Armstrong, Li, Heenatigala, \& Clarke, 2011) to the stakeholders.

Two main schools of thought laid the foundation for corporate governance theory, Agency theory and Stakeholder theory. The traditional agency relationship explains that an agent acts on behalf of another (the principal). Many agency problems arise when the goals of the principal and agent are different and conflicting (this is known as the principal-agent problem or the agency dilemma) and when it is difficult or expensive for the principal to verify what the agent is actually doing (Herrero, 2011). Further in small and family business the owner/ shareholder acts as both the principle and agent. On the other hand, all the individuals and groups who can affect or affected by the activities of a firm can be regarded as stakeholders. Stakeholder theory clarifies that managers should make decisions that take account of the interests of all the stakeholders in a firm (Jensen, 2001). These two theories consider the way that owners can structure the corporate governance systems of their business from different perspectives (Colarossi et al., 2008). However, corporate governance has wider implications, for the economic development and social well-being of a country, by way of providing incentives to achieve business performance, and accountability and transparency and to ensure an equitable distribution of wealth (Clarke, 2004).

Thus, good governance is a key factor for stable economic development. Corporate governance in developed markets has evolved gradually over centuries as a result of the economic development of industrial capitalism (Chowdary, 2003). However, compared to developed countries, corporate governance has not received as much attention in the context of developing countries (Klautzer, 2013). Further, because of economic, social, and cultural differences between developed and developing countries, the practice of corporate governance in developed countries may not the perfectly suitable for developing countries. Being a developing country, this situation is the same for Sri Lanka too.

\section{Corporate Governance in Sri Lanka}

Corporate governance of a country may depend on particular country's own contextual factors such as the political, cultural and historical characteristics of that country. Sri Lanka is a small, market oriented, developing country with average lower middle income levels. The origin of corporate governance goes back prior to colonization, when Sri Lanka was a centralized kingship state (Heenetigala, 2011). The king was the ultimate owner of the land governing the entire country with an authoritarianism, hierarchically defined cast system ( enshrined in a distinct occupation system from highest to lowest) (Heenetigala, 2011), and rituals. No governance of separate enterprises seemed necessary since economic activities were organized within the framework of the cast system.

After the kingship regime, Sri Lanka was subjected to centuries of Portuguese, Dutch and British domination (Wellalage, 2012). In the British era companies were governed by English Law. During this time, with the establishment of plantation companies, funds and expertise were channelled from Britain. Share trading was introduced through British investors' contribution of capital through the London stock market and the Colombo Brokers Association (Manawaduge, 2012). 
The next key point was the introduction of open system policies in 1977. With the shift from a socialist to a market oriented economy, many foreign investments flowed into the country and this led to the introduction of formal legislation to regulate companies. In 1982, the Companies Act and later the other corporate governance laws were passed regarding the functioning of the joint-stock companies and protection of investors' rights (Wellalage, 2012). The Security and Exchange Commission (SEC) was established in 1987 with the responsibility of developing rules and regulations for financial reporting and the capital market in Sri Lanka. The first Sri Lankan corporate governance code was introduced in 1997 by the Institute of Chartered Accountants of Sri Lanka (ICASL) to deal with financial aspects of corporate governance of Sri Lankan listed companies (Senaratne \& Gunaratne, 2008). This was adapted from the Cadbury Code (1992) - Financial Aspects of Corporate Governance, the first code of corporate governance introduced in UK and the first code of best practice developed based on the Anglo-Saxon model of corporate governance. Corporate governance standards were mandatory for all listed companies for the financial year starting on or after 1st April 2008. These mandatory rules were developed through a joint initiative of ICASL and SEC in consultation with the Colombo Stock Exchange (CSE) (Senaratne \& Gunaratne, 2007). Thus it is clear that the development of corporate governance best practices for Sri Lankan companies have gradually proceeded over a period of time from the introduction of the first code of best practice in 1997 to the introduction of minimum rules of corporate governance for mandatory compliance of listed companies in 2008.

Therefore, it is evident that the development of corporate governance best practices in Sri Lanka has been heavily influenced by British models and systems, derived from the Anglo-Saxon (market based) model of corporate governance. Hence, the notable feature of corporate governance reforms in Sri Lanka is the close allegiance with the Anglo-Saxon model of corporate governance (Senaratne \& Gunaratne, 2008). However, from an ownership perspective and a banking relationship perspective, Sri Lanka's corporate governance system is very different from the Anglo- American system (Wellalage, 2012). This argument can be supported the findings of Senaratne and Gunaratne (2007) that the concentrated ownership structure of many Sri Lankan listed companies, with a controlling shareholder and a family or a group of closely related individuals as the ultimate owner, strongly influences the governance structure and practices especially the appointment and independence of directors.

This high degree of ownership concentration, acts as a hindrance to an active takeover market and a liquid stock market. Plus a low number of arms-length institutional shareholders is very frequent in Sri Lankan companies. This situation is closely associated with the variation in the socioeconomic and political conditions of Sri Lanka that are unlike those of Anglo-American countries. Compared to these countries, Sri Lanka is a collectivistic society, which promotes family ownership. The investments of the general public in the CSE are low, which in turn to a certain extent is associated with elitism (i.e. dominance of an elite group of businessmen or families) and an emerging business class with political power and patronage in the Sri Lankan society. (Senaratne, 2011). Further according to Edirisuriya (2007), Sri Lanka's corporate structure is dominated by banks in the financial sector. Banks are the primary financial supporters of companies and the two often have complex and long relationships. Due to a weak legal structure and undeveloped microeconomic environment, Sri Lankan companies are highly dependent on banks for capital funding and Sri Lanka's corporate debt level is significantly less than developed countries (Wellalage, 2012). According to the "Investment Climate Report" (2009), state sector banks are dominant in the banking sector and comprise $40 \%$ of total banking sector assets. These characteristics of ownership - the bank-company relationship, debt, and government interventions - work to create a structure in the micro economic environment. In which state interference is comparatively higher in Sri Lanka than in other Anglo-American model countries. Therefore, the Sri Lankan model of corporate governance mechanisms is distinguished from the Anglo- American model and creates a unique corporate governance environment.

McKnight and Weir (2009) and Ward and Filatotchev (2010) reported that the efficiency of corporate governance mechanisms associated with publicly listed companies is the subject of extensive ongoing research in the literature. The same situation could be seen in literature belonging to Sri Lankan 
corporate governance. It is evident that much less is reported on governance of small firms. As a reason for that, in 2011, Wellalage and Locke pointed out that the limited data available for research on corporate governance in smaller firms undoubtedly has contributed to the limited literature concerning governance in smaller firms. More interestingly even less was reported on family firms regardless of the size of family firms. Therefore, this paper is an effort to contribute the existing knowledge base by adding literature on family firms' governance.

\section{Corporate governance in family firms in general}

Throughout the evolutionary process of family business, various and numerous definitions of family business could be seen, but still there is no one common definition. Among the numerous definitions of family business, which are gathered around the ownership in the book of "Family Business in Tourism and Hospitality" by Getz, Carlsen, and Morrison (2004), family business is defined as any business venture owned and or operated by an individual, couple(s) or a family. Further Chua, Chrisman, and Sharma (1999) defined family business as firms that are owned and managed by family members and seek to ensure trans-generational involvement through the family (Chua, Chrisman, \& Chang, 2004). Olson et al. (2003) defined family business as a business that was owned and managed by one or more members of a household of two or more people related by blood, marriage or adoption. Hence, many companies are founded as family businesses (Brenes, Madrigal, \& Requena, 2011). Accordingly, it is an important fact that empirical research highlights the predominance of family-owned firms around the world, particularly in emerging markets, including business with the least restrictive definitions of family involvement in a firm (Sharma \& Nordqvist, 2008). Therefore, a family business can be defined as a company mostly owned and managed by a single root family. In family owned or controlled businesses, families hold and control a major part of the economy and therefore they design the governance structures that benefit them. Further Neubauer and Lank (1998) revealed that the key elements of a typical corporate governance structure for a family business are the family and its institutions, the board of directors and top management. Hence, family firms rely on the concentration of ownership to achieve the same objectives set out by mandated corporate governance practices.

The complex interaction between the family and the firm creates several difficult governance issues (Wellalage \& Locke, 2011). For instance, the ownership and control, succession, performance, and governance structures are frequently discussed. This is a common situation in any economy. Mallin (2004) who claims that, when a family business is at stage when it is becoming more difficult to manage, it effectively impedes its efficient operation and development. Then is the time to develop more formal governance structures. Therefore it is clear that governance is highly related to family businesses and their growth.

Succession is a crucial factor, among the critical factors leading to problems within family businesses (Brenes, Madrigal, \& Molina-Navarro, 2006). Family business continuity plans commonly establish a governance structure for the family and for the family business (Brenes et al., 2011). The purpose of those structures is to improve strategy and control mechanisms of the family business and, to organize the communication and relationship between family owners and business executives (Brenes et al., 2011). Beside the supervision and control of management, family businesses need to establish governance structures that enhance cohesion and shared visions within the family, while at the same time reducing harmful conflicts (Mustakallio, Autio, \& Zahra, 2002). Correspondingly, the consideration of the family dimension (i.e. family governance) is an integral part of the governance structure of family firms (Klein, 2009 as in (Siebels \& Knyphausen-Aufseß, 2012)).

From the performance perspective, research by Anderson and Reeb (2003) and Villalonga and Amit (2006) find that family firms outperform non-family firms. And Andersona, Mansib, and Reeb (2003) show that family firms incur lower debt cost relative to non-family firms as well. Moreover, based on the size of the family business, or whether the business is listed or not, governance structures of family business may have differences. Further the stage of development of a family enterprise impacts the governance structure (Neubauer \& Lank, 1998). 
Siebels and Knyphausen-Aufseß (2012) disclosed through the previous literature that following a systems approach, the internal governance of a family firm is defined as two interacting subsystems: the business and the family governance system. The business governance subsystem is defined as the organization of administration and control of the business and consists of the top-management team (TMT), board of directors and shareholders' meeting. The family governance subsystem is designed to secure and organize the cohesion within the family and consists of a family governance system (Gallo and Kenyon- Rouvinez 2005 as in (Siebels \& Knyphausen-Aufseß, 2012)). The board of directors and the family council are core elements of the governance structure of a particular family business.

Though there is no universally accepted single theory or view that makes sense either in governance generally, nor in family firms in particular, a governance structure aids the achievement of goals of a family business through direction and supervision. As a consequence the governance discussion in the family business field has received much attention during the past years (Pieper, 2003). Moreover the focus of research on family business governance has evolved over time, from an almost exclusive focus on individual governance bodies and structures, mainly on the role of the board of directors in the family firm, to a different approach emphasizing the governance system as a whole (Pieper, 2003).

\section{Corporate governance in family firms in an Asian Context}

Hofstede (1994) revealed that Asian societies are collectivistic societies, which show concern for much wider group interests and emphasize belongingness that can extend to organizations. Consequently, Khan (2003) highlighted that the predominant form of large and medium scale enterprises in developing Asia are family-controlled or family-owned. Similar to Khan's statement, in Sri Lanka too, Senaratne and Gunaratne (2007) found that the ownership structure of Sri Lankan companies is largely characterized by family-controlled, pyramid, cross-holdings, with the controlling shareholder usually being another corporate entity. Based on the study done by Masulis, Pham, and Zein (2009), it was concluded that family business groups are more important in emerging markets. For example, they further revealed that the proportion of listed firms belonging to family business groups is at least 30 percent in Chile, Colombia, Israel, Philippines, Sri Lanka, and Turkey, with Sri Lanka being the largest at 64 percent. Further, Senaratne and Gunaratne (2007) found that the ultimate controlling shareholder in most Sri Lankan companies is an individual or a family as in most other Asian countries. More interestingly, according to KPMG web site Sri Lankan Family Businesses are playing a significant part in the impressive recovery of the domestic economy ("http://www.kpmg.com,")

Even though in this literature review, it was expected to discuss corporate governance of listed family business and non-listed family business in Sri Lanka, it was found that the research studies on corporate governance of non-listed family business are very limited.

\section{Corporate governance of listed family Businesses in Sri Lanka}

Mustakallio et al. (2002) found with their research that the corporate governance in family firms differs from that in non-family firms because owners have multiple roles in a family business. In the Sri Lankan context, where family-owned or controlled companies are the prominent type of business organization, this is the case not only in small and medium scale companies in Sri Lanka, but Masulis et al. (2009) found that $64 \%$ of listed companies too are family controlled. As explained by Shenoy (2014), Hemas Holding Group Director, Abbas Esufally revealed the main reasons that a family business tends to be publicly listed are incentives, compliance, attracting top people, and the need of funds. To elaborate this further, Manawaduge and Zoysa (2013) disclosed that most of the Sri Lankan firms have stable ownership structure and therefore ownership is more likely to be exogenous to performance. Furthermore, direct managerial ownership in Sri Lankan companies is relatively small, because ownership is usually dominated by another corporate entity. These entities usually have family ownership as the ultimate owners, and therefore, direct managerial ownership does not play an 
influential role in the Sri Lankan context. And the existence of family ownership as a controlling shareholder, either through direct ownership or through another corporate entity, is a common feature of Sri Lankan listed companies. Hence, the key concern of family ownership is that it leads to the majority of directorships in these companies being held by the family members and the transferring of the management of the companies from one generation to another of the controlling shareholder family.

Supplementary to this, inadequacies in the Sri Lankan legal structure for the protection of investors' rights have also contributed towards the presence of a controlling shareholder (Senaratne, 2011) . Further the study done by (Wellalage \& Locke, 2011) found that traditional corporate governance mechanisms cannot mitigate principal-principal agency conflict in family firms in emerging markets. More importantly, their study indicated a requirement for the promulgating or streamlining of corporate laws in emerging markets to reduce the possibility of expropriation of minority shareholders by politically-powered family firm owners.

\section{Corporate governance of Non-listed large family Business in Sri Lanka}

Due to the absence of empirical studies specific to the governance of non-listed family business, this section is primarily based on the valuable facts revealed by an article written by Shenoy (2014) in Daily Fit e-paper relating to the seminar on 'Family Owned Businesses' conducted by the Sri Lanka Institute of Directors at the Cinnamon Grand, Colombo (2014). The participating family business leaders in a panel discussion confirmed that that the engine of growth in the Sri Lankan economy has been the private sector, with family-run businesses from small to large scale.

\section{Family Involvement in Governance}

Family governance is distinguished not by the separation but by the unification of ownership and control (Carney, 2005). This makes family business different from widely-held corporations. At the same time this makes governance in family business more complicated due to not being able to apply a typical corporate structure because of the central role that the family plays in ownership and management (Faizal Salieh as in Shenoy, 2014). Therefore, family businesses are governed within unique governance structures which are unique to individual family businesses. Hence, a family dimension is an integral part of family business governance and also the cause of the difficulties in management. Further impact of family members who do not actively involve in family business is also very vital for the family business continuation. To explain this further the statements of active members of leading Sri Lankan family businesses which are not listed could be used:

"In our case, it's the role our mother plays, although she wasn't actively involved in the business. If we took decisions without telling our father, we'd get a call from mother telling us off. So in a way, it was a form of informal governance and balance in keeping the family together".

"Our unwritten rule, with just six of us, is that whatever disagreements we have, we discuss it in the evening. As a family rule, we talk to each other every day. Not a day goes by without things being resolved at the end, and the next day it goes back to business as usual".

"We too have structured family meetings once a week, discussing either business or personal aspects. No phones, no interruptions for one hour. A lot is achieved".

Elaborating this further, to handle emotional issues which could not be handled with a corporate approach, the role of "Chief Emotional Officer" (Faizal Salieh as in Shenoy, 2014) should be played by an appropriate individual in a family business. This would help to overcome agency problems and reduce the negative aspects of altruism. Hence, it is evident that explicitly or implicitly a Sri Lankan 
family business uses a family council to govern the business. This would be formal or informal as evident by the above.

\section{Decision Making}

Basically founders of family businesses tend to make decisions at their own risk and calculate their own rate of return. However, with the next generation's involvement, decision making becomes more formalized and decisions are made via risk committees and other formal bodies. By explaining this situation further major Sri Lankan family business leaders have agreed that though founders put more weight on their inner feelings and intuition, structured governance is truly important for the next generations. As the reason for this, one of the family business leaders, (Shenoy, 2014) expressed his view as

"A lot of things in the early day were based on gut and emotion. Public companies and families are two different things, and we're trying to find a happy medium. The gut feeling is exciting, but rational decisions must be made".

More importantly another key point he made was that with the end of the war many businesses needed longer term investment policies and for that a more structured way of governance as indeed need. This does not suggest that the only important mechanism is formal rules and regulations to govern the business. However as family business members have the freedom to do so, their own way of making decisions could be used when it is needed. This is indicated by the statement stated in Shenoy (2014) as

"If all the rules and regulations worked, I wouldn't be here. It is gut feeling that brings people to their decisions. When I was about 29, I recall telling my dad not to buy something as I didn't feel we could afford it. Now of course, we have different advisors and committees. But at the end of the day the gut feeling needs to govern you sometimes. If you're bogged down by committees, the business cannot grow".

Therefore it is clear that decision making processes in family businesses unlike in other corporate bodies is a two-phase process which involved both rational decision making process as well as family members' intuition.

\section{The future of Sri Lankan Family Business}

Family businesses tend to turn into public listed companies due to several reasons, such as capital for growth, attracting talent employees, seeking foreign investments, to lessen the agency problems. However, the strategy they would prefer to practice, is making their subsidiaries public and keeping hold the company as a family business. This was confirmed at the seminar on 'Family Owned Businesses' conducted by the Sri Lanka Institute of Directors at the Cinnamon Grand (2014). The participating family business leaders in a panel discussion agreed that, along with a rational justification to be public, it would be appropriate to be a listed company. On the other hand, the best option would be listing subsidiaries while keeping the holding company a family business. Further, they revealed their strategy of partnering with big publicly listed companies in terms of the betterment and continuation of the family business in future.

\section{Corporate Governance of Small to Medium family business in Sri Lanka}

Corporate governance of family business may have differences occurring with the changes in the size of the business. Even though corporate governance practices are not compulsory for non-listed family business, many large family businesses which are not registered in the Colombo Stock Exchange do follow formal corporate governance practices such as forming a Board of directors and relevant committees. However, this situation could be different in relation to small and medium size family 
businesses since they do not follow many rules and regulations apart from a few that are compulsory such as registration of the name of the business and other tax related requirements. Further, studies done with small and medium enterprise (SME) in Sri Lanka revealed that many SMEs are sole or family owners. Findings of the study conducted by (Dissanayake \& Kodithuwakku, 2011) revealed that there exists a positive relationship between the supportive family member contribution and the small family business success. Furthermore, most successful small family businesses received support from their family members via emotional, instrumental social (paid/unpaid work), instrumental material support (financial and/or other resource needs) and nominal forms. Nominal or dummy contributions of family members is a new form of family member support which emerged during the initial phase of their study, it is defined for the purpose of the study as the support the family members extend to the business through their fame, recognition and/or societal status without actively contributing to the business operations via any other identified forms of contributions. Dissanayake and Kodithuwakku (2011) concluded that the more a given business receives family member support through all forms of identified contributions the more the small family business success will be. Further in many SMEs in Sri Lanka the owner is the ultimate decision maker whose concern with the formal process of director boards, committees and meetings on managing and controlling the business are very rare (Weerakkody, 2009). However, still published studies relevant to this area are very less. Therefor there is a significant need to conduct empirical research on governance in small and medium family businesses in Sri Lanka.

\section{Conclusion}

The key concern of family ownership is that it leads to the majority of directorships in these companies being held by the family members and transferring the management of the companies from one generation to another of the controlling shareholder family. With the constraints of the lack of previous studies in governance in family business, this study followed some key facts revealed by leading Sri Lankan family business members at the seminar on 'Family Owned Businesses' conducted by the Sri Lanka Institute of Directors at the Cinnamon Grand, Colombo, Sri Lanka in 2014. The participating family business leaders in panel discussion disclosed that the family plays a critical role in governance with family discussions and meetings. More formally, this could be called family meetings or councils. Further they confirmed that unlike in other corporations, governance in family business is a two-tier mechanism involving both unstructured and structured components in governance process and decision making. Specially, though, managing a business with one's own intuitive style sits well with founders. Written down formal governance process is required with the involvement of second and third generations. More importantly converting the business into listed public company is dependent on the needs of the business and this is not essential for growth. Further a Sri Lankan family business, with the right balance of business and family, could perform best with the involvement of several generations. This was evident in the Hirdaramani Group, one of leading apparel family business in Sri Lanka, which is governed by the fourth generation (Shenoy, 2014). Hence, as an emerging economy Sri Lanka has benefitted by family business. On the other hand governance in Sri Lankan family business as a field of research suffers from a lack of literature and empirical studies. Very few empirical studies on listed family business governance and no any empirical study on non-listed family business governance could be seen. Therefore these areas can be researched further based on different factors. For instance, a study could find out whether there are differences in non-listed family business governance based on size as small, medium, and large. Moreover, no study could be found on differences between listed and non-listed family business governance. Hence, this would be a great opportunity for researchers to explore and find fruitful facts relating to family business governance in an emerging economy. 


\section{References}

Adams, M., Armstrong, A., Clarke, A., Clarke, T., Eddie, I., Heenetigala, K., . . . Richardson, A. (2011). "Developing a responsive regulatory system for Australia's small corporations: governance for small business.: Australian Research Council Linkage Grant

Anandarajah, K. (2004). Corporate Governance in Asia in a Post-Enron World he Practitioner's Guide to Corporate Governance in Asia. Hong Kong: ISI Publications Limited.

Anderson, R. C., \& Reeb, D. M. (2003). Founding-Family Ownership and Firm Performance: Evidence from the S\&P 500. THE JOURNAL OF FINANCE, 58(3), 1301-1327.

Andersona, R. C., Mansib, S. A., \& Reeb, D. M. (2003). Founding Family Ownership and the Agency Cost of Debt. Journal of Financial economics, 68(2), 263-285.

Armstrong, A., Li, Y., Heenatigala, H., \& Clarke, A. (2011). Developing a Responsive Regulatory System for Australia"s Small Corporations: Governance for Small Business. Melbourne: Victoria university.

Brenes, E. R., Madrigal, K., \& Molina-Navarro, G. E. (2006). Family business structure and succession: Critical topics in Latin American experience. Journal of Business Research, 59(3), 372-374.

Brenes, E. R., Madrigal, K., \& Requena, B. (2011). Corporate governance and family business performance. Journal of Business Research, 64(3), 280-285.

Chowdary, N. V. (2003). Corporate Governance In Emerging Markets Corporate Governance (Vol. 1). Hyderabad: ICFAI Press.

Chua, J. H., Chrisman, J. J., \& Chang, E. P. C. (2004). Are Family Firms Born or Made? An Exploratory Investigation. Family Business Review, 17(1). doi: 10.1111/j.17416248.2004.00002.x

Chua, J. H., Chrisman, J. J., \& Sharma, P. (1999). Defining the Family Business by Behavior. Entrepreneurship Theory and Practice, 23(4), 301-330.

Clarke, T. (2004). Theories of Corporate Governance: The Philosophical Foundations of Corporate Governance. London and New York: Routledge.

Colarossi, F., Giorgino, M., Steri, R., \& Viviani, D. (2008). Corporate Governance Study on Italian Family Firms. Corporate Ownership \& Control, 5(4), 93-103.

Dissanayake, C. K., \& Kodithuwakku, S. (2011). Family Member Contribution on the Success of Small Family Businesses: A Case Study on Brassware Businesses in Kandy. Paper presented at the International Conference on Business Management, Sri Lanka.

Edirisuriya, P. (2007). Effects of financial sector reforms in Sri Lanka: evidence from the banking sector. Asia Pacific Journal of Finance and Banking Research, 1(1).

Gabrielsson, J., \& Huse, M. (2004). Context, Behavior, and Evolution: Challenge in Research on Boards and Governance. International Studies of Management and Organisations, 34(2), 1136.

Getz, D., Carlsen, J., \& Morrison, A. (2004). Family Business in Tourism and Hospitality. Wallingford, U.K. ; Cambridge, MA: CAB International.

Hart, O. (1995). Corporate Governance: Some Theory and Implications. The economic journal, 105(430), 678-689.

Heenetigala, K. (2011). Corporate Governance Practices and Firm Performance of Listed Companies in Sri Lanka. (Doctor of Business Administration), Victoria University, Melbourne.

Heenetigala, K., \& Armstrong, A. (2011). The Impact of Corporate Governance on firm performance in an unstable economic and political environment: Evidence from Sri Lanka. Paper presented at the 3rd Conference on Financial Markets and Corporate Governance.

Herrero, I. (2011). Agency Costs, Family Ties, and Firm Efficiency. Journal of Management, 37, 887905

Hofstede, G. (1994). The business of international business is culture. International business review, $3(1), 1-14$.

http://www.kpmg.com. Retrieved 04/01/2014, 2014 
. Investment Climate Statement - Sri Lanka. (2009). Colombo: Bureau of Economic, Energy and Business affairs.

Jensen, M. C. (2001). Value maximization, stakeholder theory, and the corporate objective function. Journal of applied corporate finance, 14(3), 8-21.

Klautzer, L. C. (2013). Can Economic Openness Inspire Better Corporate Governance? An Exploration of the Link between Openness and Corporate Governance based on the Asian Experience. (doctoral degree in public policy analysis), RAND Corporation, USA.

Licht, A. N., Goldschmidt, C., \& Schwartz, S. H. (2005). Culture, Law, and Corporate Governance. International Review of Law and Economics, 25, 229-255.

Mallin, C. A. (2004). Corporate Governance. New York: Oxford University Press.

Manawaduge, A. S. (2012). Corporate governance practices and their impacts on corporate performance in an emerging market: the case of Sri Lanka. (Doctor of Philosophy), University of Wollongong, New South Wales, Australia.

Manawaduge, A. S., \& Zoysa, A. D. (2013). The Structure of Corporate Ownership and Firm Performance: Sri Lankan Evidence. Corporate Ownership \& Control, 11(1), 723-734.

Masulis, R. W., Pham, P. K., \& Zein, J. (2009). Family Business Groups around the World: Costs and Benefits of Pyramids. Review of Financial Studies, 24(11), 3556-3600.

McKnight, P. J., \& Weir, C. (2009). Agency costs, corporate governance mechanisms and ownership structure in large UK publicly quoted companies: A panel data analysis. The Quarterly Review of Economics and Finance, 49(2), 139-158.

Mustakallio, M., Autio, E., \& Zahra, S. A. (2002). Relational and Contractual Governance in Family Firms: Effects on Strategic Decision Making. Family Business Review, 15(3), 205-222.

Neubauer, F., \& Lank, A. G. (1998). The family business: Its governance for sustainability: Macmillan.

Olson, P. D., Zuikera, V. S., Danesa, S. M., Staffordb, K., Heckc, R. K. Z., \& Duncan, K. A. (2003). The impact of the family and the business on family business sustainability. Journal of Business Venturing, 18, 639-666.

Pieper, T. M. (2003). Corporate Governance in Family Firms: A Literaure Review. Paper presented at the Doctoral Track Proceedings of the 14th FBN-ifera Annual World Conference Research Forum.

Ramon, V. (2001). Corporate Governance as Competitive Advantage in Asia: Managing Corporate Governance in Asia. Asian Institute of Management.

Rezaee, Z. (2009). Corporate Governance and Ethics. USA: John Wiley \& Sons Inc.

Senaratne, S. (2011). Corporate Governance Reforms in Sri Lanka. Sri Lanka Journal of Advanced Social Studies, 1(1), 1-25.

Senaratne, S., \& Gunaratne, P. S. M. (2007). Significant features and associated issues of corporate governance practices of Sri Lankan listed companies. Paper presented at the International Research Conference on Knowledge for Growth and Development, Sri Lanka.

Senaratne, S., \& Gunaratne, P. S. M. (2008). Corporate Governance Development in Sri Lanka: Prospects and Problems. Paper presented at the International Research Conference on Management, University of Colombo, Sri Lanka.

Sharma, P., \& Nordqvist, M. (2008). A classification scheme for family firms: From family values to effective governance to firm performance Family Values and Value Creation: The Fostering Of Enduring Values Within Family-Owned Businesses (pp. 71-101). Basingstoke: Palgrave MacMillan.

Shenoy, K. (2014). Transforming family-owned businesses: What does it take?, DailyFit e-paper

Siebels, J.-F., \& Knyphausen-Aufseß, D. z. (2012). A Review of Theory in Family Business Research: The Implications for Corporate Governance. International Journal of Management Reviews, 14(3), 280-304.

Villalonga, B., \& Amit, R. (2006). How do family ownership, control and management affect firm value? Journal of Financial economics, 80(2), 385-417.

Ward, D., \& Filatotchev, I. (2010). Principal-principal-agency relationships and the role of external governance. Managerial and Decision Economics, 31(4), 249-261.

Weerakkody, W. A. S. (2009). Master of Science in Management), University of Sri Jayewardhenapura, Sri Lanka. 
Wellalage, N. H. (2012). Corporate Governance and Financial Performance of Sri Lankan Listed Companies 2006-2010. (Doctor of Philosophy), University of Waikato, New Zealand.

Wellalage, N. H., \& Locke, S. (2011). Agency Costs, Ownership Structure and Corporate Governance Mechanisms: A Case Study in New Zealand Unlisted Small Companies. International Research Journal of Finance and Economics(78), 178-192. 
